\title{
The Determinants Of Foreign Location And Market-Entry Mode By Multinational Banks: A Simultaneous Approach
}

Samia Belaounia, Ph.D., NEOMA Business School, France

Tawhid Chtioui, Ph.D., ICD International Business School, France

Mehdi Nekhili, Ph.D., University of Maine, France; ICD International Business School, France

\begin{abstract}
The study aims to explain the determinants of banks' choices of location of overseas activities and of market-entry mode (subsidiary, branch and representative office). Location of overseas activities and market-entry mode are considered as simultaneously determined. The determinants are based on the factors associated with the characteristics of the parent bank and host country. A 3SLS model is used to estimate these determinants. Based on sample of 63 banks from 18 countries in 2004, the results show that foreign location and market-entry mode are governed by the characteristics of both the host country and the parent bank. Our results also provide some answers about the impact of entry mode on location choice, and vice versa.
\end{abstract}

Keywords: Multinational Banks; Foreign Location; Entry Mode; Simultaneous Approach

\section{INTRODUCTION}

O nder the influence of the World Bank and the International Monetary Fund (IMF), and amid market saturation in developed regions, recent privatization policies and the relaxation of banking regulations in developing ('emerging') and transition countries have contributed to promoting banking internationalization. The majority of foreign direct investment (FDI) in the banking industry is concentrated not only in developing countries (Dunning and Lundan, 2008), but also in transition economies. As shown by the Global Financial Stability Report published in 2007 by the IMF, foreign-bank participation in the banking systems of emerging (or transition) countries increased significantly between 1995 and 2005, albeit at different rates in different areas (Cull and Martinez Peria, 2010). For example, in 2008, the proportion of assets held by foreign banks exceeded 90\% in Central and Eastern Europe (UNCTAD, 2010). A good example is the Czech Republic, where the vast majority of banks are owned by foreign financial institutions. In the case of Asia and Latin America, the more relaxed entry restrictions introduced in the mid-1990s (as a 'post-crisis' effect) also appear to have promoted foreign-bank entry (Cull and Martinez Peria, 2007).

Regardless of one's point of view or research perspective, any attempt to account for this tendency requires identification of the factors governing the choice of location. A range of explanations has been given in the literature. Distance appears to be a key factor influencing the choice of location, and is at the root of increased managerial complexity, resulting in greater demands in terms of information processing. Without ignoring or underestimating the various issues raised by its use as an explanatory factor, distance can be used and understood in various ways (Brewer, 2007): It is not merely geographical but may also include cultural, administrative (or legal) and economic distance (Ghemawat, 2001). Research on the banking sector also often focuses on the level of economic development of the host country (Focarelli and Pozzolo, 2005) and the nature of banking regulations there (Buch, 2005; Claessens and Van Horen, 2008). In examining the specific characteristics of firms, research tends to focus on company size (Focarelli and Pozzolo, 2005) and experience of internationalization (Mutinelli and Piscitello, 2001). Size is measured by the financial and human-resource capacity required to absorb the high costs associated with international development. Experience of internationalization is assessed based on evidence of the managerial skills required to manage the complexities of coordinating culturally diverse teams at an international level. 
In order to enter a foreign market, banks must choose both a particular location and a specific entry mode (or organizational form). The latter must enable them to adapt not only to the new market according to their own characteristics and those of the host country, but also to the cultural, linguistic, economic and institutional differences between the home and host countries. As noted by Goldberg and Saunders (1981), banks can enter foreign markets by setting up a subsidiary, a branch or a simple representative office. Their (operating and financial) autonomy from the parent bank may distinguish them. As such, a branch is not independent from the parent firm, even if its operating regulations (accounts, statement of income, etc.) imply some degree of autonomy. Branches perform a range of commercial activities and also have their own clientele, but have no legal autonomy. Unlike a branch, a subsidiary is a legally autonomous entity. A subsidiary is autonomous from the parent firm, can take legal action, and has its own capital (Tschoegl, 2004). Representative offices are the least expensive option available to banks seeking to enter foreign markets (Blandón, 1998), requiring only two or three employees. In addition, representative offices have no capital of their own and no legal personality, operating under the control of the parent company. Yet when organizational forms are considered, the representative office is rarely taken into account.

In spite of the importance of the choice of entry mode, as Cerutti et al. (2007) point out, empirical research on banking internationalization has often overlooked the specific organizational form used by banks to expand abroad. Moreover, in most cases, when studied, these two fundamental decisions (location and entry-mode choice) are examined separately, despite their being strongly connected. For instance, choosing the location in line with specific factors makes a particular organizational form more relevant. In the words of Hryckiewicz and Kowalewski (2010), who studied foreign entry in Central Europe, "in principle, the factors affecting the decision about entry into the Central Europe countries may vary with the mode of entry chosen by a bank". Hryckiewicz and Kowalewski therefore test for the influence of specific factors, first on the entry decision, and then on the organizational form (subsidiary or branch). As a matter of fact, since both decisions depend on the same explanatory factors, this alone represents the formal expression of their interconnection.

In general, studies in this area focus on a single area or host country - e.g. the United States in the case of Goldberg and Saunders (1981) and Grosse and Goldberg (1991, 1994), Japan and Korea for Ursacki and Vertinsky (1992), Italy for Magri et al. (2005), the countries of the Organization for Economic Co-operation and Development (OECD) for Cerutti et al. (2007), and Latin America for Yeyati and Micco (2007). Only a small number of studies have examined the determinants of bank location in emerging or transition countries.

Our work aims to contribute to the existing literature on foreign-bank location and entry-mode choice, considering both decisions through endogenous and interconnected variables. It also aims to provide a more comprehensive overview of the field by examining the three types of foreign-market-entry strategy or organizational form (i.e. branches, subsidiaries and representative offices) in five different regions (Africa, Central and Latin America, Eastern Europe, Southeast Asia, and the Middle East). The paper focuses on developing and transition economies, whereas the existing studies involve in most cases developed countries as the major destination of FDI since the early 1990s (Cull and Martinez Peria, 2010). The particular scope of this study relates not only to the internationalization strategy used by banks entering countries that are economically close to their home countries. Foreign institutions often seek to enter emerging or transition markets in order to take advantage of the new growth opportunities in these countries, while the purpose of entering markets in developed countries is to develop customer-service policy (Clarke et al., 2000).

The remainder of the paper is organized as follows. Section I presents the conceptual framework and focuses on the factors determining location choice and the organizational form, as highlighted in the existing literature on the banking sector. Hypotheses are proposed for each determinant, in order to explain both the location and the entry mode. Section II focuses on the research methodology and presents the sample, the studied variables and the model. The model highlights the specific location choices for each of the organizational forms defined in section one; these decisions are both simultaneous and interdependent. Incidentally, the model takes into account the effect of location on foreign-market-entry mode and vice versa. Section III presents and discusses the results, while section IV draws some conclusions. 


\section{CONCEPTUAL FRAMEWORK AND HYPOTHESES}

\subsection{Explanatory Factors Related to The Host Country}

\subsubsection{Regulation}

The regulatory framework of the host country is a key factor in the choice of location, particularly in banking, which is by nature a highly regulated industry. Rupprecht (2008) modeled the influence of regulation on location choice to minimize total costs, including operational, financial and transaction costs (Williamson, 1990). Banking regulations focus mainly on capital requirements and the range of activities they impose on banks. In substance, the model developed by Rupprecht (2008), irrespective of the risk profile of the credit institution, suggests that relatively restrictive capital regulations, through reserve requirements as a fixed percentage of the bank's commitments, have a positive impact on foreign-market entry, and contribute to stabilizing the financial system and preventing liquidity crises. This gives more guarantees to depositors, who want the lowest-risk premium, from which the bank derives a cost advantage. In the same way, the empirical results of the study by Claessens and Van Horen (2008) highlighted the attractiveness of high-quality prudential institutions and the relaxation of entry restrictions as key factors that positively affect market entry. Buch (2005) argued that a strong legal tradition, similar to the legal framework of the host country, provides reassurance to foreign banks and has a significant positive impact on foreign-market entry through the subsidiary - an organizational form that allows for a greater level of involvement in the host country. Thus, Buch (2005) does not disconnect the location choice from the entry-mode choice.

Besides, when regulation restricts the banking activity, it appears to discourage foreign entry, as shown by several empirical studies. In the case of emerging economies, the relaxation of restrictions on entry to Argentina, Brazil and Mexico in the mid-1990s (a post-crisis effect) resulted in a significant increased presence of foreign banks in these countries (Moreno and Villar, 2005). In the same period, the Asian financial crisis appears to have had similar effects (Montgomery, 2003). More recently, Birindelli and Del Prete (2010) show, using a sample of Italian banks, that, after controlling for the effect of path dependency on the likelihood of entry, regulatory constraints (measured according to the index of Barth et al., 2003) tend to discourage entry.

On the other hand, regulation of the host country appears to have a strong effect on the entry mode. Cerutti et al. (2007) test the impact of regulatory treatment of branches versus subsidiaries by the host country through an index combining various kinds of requirements: notably "the written requirements, the restrictions on activities, the responsibilities undertaken". The branch is compared to the subsidiary for each dimension, through a dummy variable, equal to 1 when more requirements are associated with the foreign branch. The restrictions also concern the type of activity and its scope. Indeed, the bank's ability to provide credit and loans is affected by its organizational form. Branches appear to be favored in the case of a wholesale orientation, while subsidiaries are more often selected when operating with local clients (Focarelli and Pozzolo, 2005), that is with a retail orientation. Indeed, in most cases, retail banking is kept separate from wholesale banking (including investment banking). Cerutti et al. (2007) show that the more restrictions there are on the branch, the less likely it is that this will be the chosen mode for market entry.

In this context, the subsidiary, through acquiring an existing domestic entity, represents an opportunity to circumvent the regulatory constraints; the branch, meanwhile, typically represents a de novo operation. The subsidiary offers a broader array of financial services, and puts the bank in a better position to exploit profit opportunities associated with higher product-diversification. In fact, branch is assumed to be less preferred to the subsidiary where there are strong written activity restrictions.

H1a. More constraining regulation (in terms of entry conditions and written requirements) tends to discourage foreign entry.

H1b. More constraining regulation (in terms of entry conditions and written requirements) tends to favor the subsidiary as an entry mode over the branch. 


\subsubsection{Level of Economic Development}

In line with the eclectic theory developed by Dunning (2001), the specific advantages of the host country are assumed to influence foreign-market-entry decisions. A number of studies of the banking sector have provided evidence of the impact of various factors, such as the size of the financial system (Goldberg and Grosse, 1994), revenue (Brealey and Kaplanis, 1996; Buch, 2000) and per capita income (Goldberg and Johnson, 1990; Yamori, 1998; Claessens et al., 2000) in the host country. In a study of European transition economies, Carstensen and Toubal (2004) found several factors had a positive impact, including the potential market, the unit cost of labor, the presence of a qualified labor force and, uniquely, the level and mode of privatization. Overall, the potential for economic growth appears to be one of the most significant factors governing a bank's decision to enter a foreign market.

Internationalization appears to be a way of maintaining control over the commercial relationship beyond the frontiers of the home country, which amounts to the 'follow-the-customer hypothesis' (Berger et al., 1995; Yamori, 1998; Buch, 2000; Miller and Parkhe, 2002), an issue that applies only to larger banks with an international clientele. More specifically, Miller and Parkhe (1998) validate the postulated positive relationship between the level of banking services in the host country and the FDI, for the three organizational forms (branch, subsidiary, and representative office), without comparing them as such, and only in industrialized countries. This would validate the 'follow-the-customer' hypothesis' in order to value information capital and internalize informational assets, which are bank-specific. The absence of such a relationship for the developing countries may be traced to the debt crisis experienced in Latin America in the mid-1980s.

In addition, when a foreign bank belongs to a more efficient banking and financial system, it is able to offer more sophisticated, innovative and lucrative financial services on competitive terms. Moreover, in the poorer countries, where the banks are less capitalized, efficient and effective, it is easier for the foreign entities to compete against the domestic ones. Focarelli and Pozzolo (2005) emphasized the competitive advantage associated with foreign-market entry through branches. They also showed that a low per capita gross domestic product (GDP) has a positive influence on the decision to enter a foreign market when there are growth prospects, the capital and credit markets are well-developed, and inflation is low. According to Focarelli and Pozzolo (2005), a low GDP is not a major handicap if there is a strong tradition of banking among the population of the host country. To determine the level of development and to identify the prospects for economic growth in a given country, the focus tends to be on the rate of penetration of banking services, measured by the deposit-to-GDP ratio (Focarelli and Pozzolo, 2005).

Furthermore, when the level of economic development is high, the subsidiary, associated with bigger operations, appears to be a more likely organizational form than the branch or representative office. According to Blandón (1998), "the representative office is the most economical of overseas banking organizational forms". A representative office generally requires only two or three employees. It has no capital of its own and no legal personality, operating under the control of the parent firm. Additionally, a representative office is not authorized to undertake traditional banking activities such as deposit-taking and credit-granting. As a consequence, its small size compared to that of the branch and the subsidiary - would represent a significant constraint insomuch as it limits the size of the potential clientele of the parent firm in the host country. The rare studies considering the representative office show its lack of significance as an organizational form. Thus, according to Blandón (1998), the representative office appears not to have any predicting power of entry. The model includes banks choosing such an entry mode in the sub-group characterized by 'no representation abroad'. According to Ursacki and Vertinsky (1992), the ownership-specific advantages (Dunning, 2001) are not statistically significant in explaining foreign banking expansion through representative offices.

On the other hand, Focarelli and Pozzolo (2008) show a positive association between the country's growth prospects and the setting-up of a subsidiary. The level of economic development in fact reflects the volume of business that could be achieved. This relationship between economic development and the probability of setting up a subsidiary has also been empirically demonstrated by Cerutti et al. (2007), and appears to be consistent with Focarelli and Pozzolo (2005)'s findings. According to these, the growth prospects - as shown by the per capita GDP, size of the banking sector, standard of education, and inflation rate - have a more significant influence on entry when the subsidiary is the chosen entry mode. High profitability rates and cash flows, which reflect lower efficiency of the 
local banks, combined with the presence of unexploited profit opportunities (that are thus available for the foreign banks), turn out to have the same effect. We put forward the stronger capital involvement associated with the subsidiary compared to the branch in interpreting these results.

H2a. In seeking to enter a foreign market, banks choose countries with good growth prospects in the banking sector.

H2b. When the level of economic development is high, foreign banks are more likely to use the subsidiary (than the branch or the representative office) as an entry mode.

\subsubsection{Taxation}

Low taxation is conceived, according to Dunning's model, as a country-specific advantage. Thus, it positively influences the entry decision. As a consequence, banks prefer to enter countries with lower taxes. Corporate taxation also influences the entry-mode choice, because in host countries with high tax rates, the branch makes it possible to shift the profits across borders for tax-optimization reasons. In other words, the entry mode appears to be a moderator in the relationship between the taxation rate and the probability of entry. As such, Miller and Parkhe (1998) observe a higher percentage of subsidiaries in countries with relatively low tax rates, and a higher percentage of branches in countries with relatively high tax rates. This has been validated by Cerutti et al. (2007). No hypothesis states the influence of the taxation regime on the choice of the representative office. Since it has no legal personality, the representative office does not issue individual financial statements and so choosing this entry mode has no potential tax advantages.

H3a. A low taxation rate in the host country acts as an incentive for banks to enter a foreign market.

H3b. When the taxation rate is high, the branch is preferred to the subsidiary as an entry mode for foreign banks.

\subsubsection{Country-Risk}

The concept of country-risk includes regulatory, legal and political risks. Some studies of the banking sector have provided evidence of the impact of country-risk on the probability of entry (Grosse and Goldberg, 1991; Fisher and Molyneux, 1996; Yamori, 1998), while determining the profit opportunities in the host market (Grosse and Goldberg, 1991; Yamori, 1998; Carstensen and Toubal, 2004). Carstensen and Toubal (2004) attribute the attractiveness of the Central European countries to the low country-risk levels that characterize them. Furthermore, high country-risk is expected to reduce the attractiveness of a region, according to how constraining the capital regulation is there. Miller and Parkhe (1998) show that agreement by the host country of the Basel Accords' riskadjusted capital requirement has a negative effect on FDI, being perceived as reducing the profit opportunities - and so in line with country-risk as a negative influence on the entry decision. However, studying the FDI of Italian banks, Magri et al. (2005) observe no statistically significant influence of differences in country-risk between the country of origin and the host country on the likelihood of entry. On the other hand, the country-risk influences the entry mode, because the liability structures depend on the organizational form. In fact, when macroeconomic risk is high, the branch (with which a higher parent responsibility is associated) is less common than the subsidiary. Cerutti et al. (2007) study the influence of risk on the organizational form. The parent bank has full responsibility for the branch, while it is limited to the shareholders' equity for the subsidiary. As a consequence, the branch is preferred for targeting countries characterized by low economic risk (Dell'Ariccia and Marquez, 2010). The representative office is usually a first implementation step in order to accumulate knowledge about the local market in the host country, and to assess the risks and opportunities. Additionally, the representative office has no legal personality and no capital of its own, and operates under the control of the parent company. As a consequence, country-risk is unlikely to have any impact on choosing the representative office as the entry mode.

H4a. Country-risk reduces the probability of foreign-bank entry.

H4b. When the country-risk is high, the subsidiary is preferred to the branch as an entry mode for foreign banks. 


\subsection{Explanatory Factors Related to The Parent Bank}

\subsubsection{Bank Size}

Bank size is assumed to have an impact on internationalization by determining the financial and human-resource capacity required to absorb the significant costs associated with international development and foreign-market entry. Large banks are able to diversify their risks and to use economies of scope between their various activities, giving them a unitary cost advantage. Though technically different, the various activities may complement one another in the relationships with customers, who have global needs, thereby creating synergies (Stein, 2002). Finally, size is also assumed to be an asset in coping with the concentration of the banking sector in the target country, an implicit barrier to entry. Focarelli and Pozzolo (2005) highlighted the positive impact of bank size on the decision to enter a foreign market. Based on a sample of the 100 largest banks in the world, Tschoegl (1983) found a positive association between asset size and the number of foreign-based entities (according to the number of countries where banks operate).

The size of the parent bank is also expected to determine the choice of entry mode. Affecting the bank's ability to operate abroad, size is indeed expected to favor the subsidiary, which requires a larger initial investment than the branch. Miller and Parkhe (1998) and Cerutti et al. (2007) find that the branch is usually associated with relatively small operations, in particular when the affiliate is a retail bank. Consequently, the branch goes with a weaker penetration of the targeted market, as Cerutti et al. (2007) show. As for the size of the overall parent bank, this seems not to have any impact on the likelihood of selecting the branch as the entry mode. This could be explained by the sample of Cerutti et al. (2007), composed of fairly large parent banks with a low discriminating power of the size variable. More recently, studying Asian and Latin American banks between 1999 and 2005, Hsieh et al. (2010) provide evidence of a positive association between a large-scale and high-control entry mode. They do not explicitly compare the subsidiary with the branch, but more broadly they set the high-control modes against the low-control ones, with the former accompanying a high resource commitment abroad. In this respect, the representative office, even fully controlled by the parent bank, involves a lower initial investment than the branch, which in turn involves a lower commitment than the subsidiary. In fact, there is a hierarchy of the various entry modes in terms of capital commitment, increasing from the representative office (associated with preliminary implementation and small size) to the subsidiary.

H5a. The parent bank being of a significant size facilitates market entry in countries with a highly concentrated banking market.

H5b. The parent bank being of a significant size favors the subsidiary (over the branch, and then the representative office) as the foreign-market-entry mode.

\subsubsection{Experience of Internationalization}

Experience of internationalization is another key factor determining the decision to invest in foreign markets, enabling banks to better understand an international environment that is both complex and turbulent. According to Douglas and Karunaratna (2006) and Brewer (2007), experience of internationalization is also likely to reduce the so-called 'psychic' distance highlighted in the Uppsala model developed by Johanson and Vahlne (1977) and to facilitate the search for increasingly distant new markets. The Uppsala model posits that involvement in international operations occurs sequentially. A company with limited knowledge will tend to make less risky decisions (such as entering neighboring countries) before expanding its operations to more distant countries. Experience enables a company to make FDI in line with the size of its market. Experience of internationalization also enables banks to improve their relationships with staff, clients, competitors and local authorities (Mutinelli and Piscitello, 2001). Leung et al. (2008) found that experience of internationalization accelerates the decision to enter the market and slows down market exit. The results are particularly significant in the case of Asian banks.

On the other hand, Blandón (1998) argued that banks with significant international experience tend to resort to organizational forms allowing for a significant level of involvement in the banking industry of the host country. Examining the case of Italian banks, Mutinelli and Piscitello (2001) found that the choice between the branch and 
the representative office tends to be governed by the experience of foreign markets, with representative offices emerging as the preferred option in order to limit the political and economic risks. The higher the bank's experience of internationalization, the higher is its ability to operate in a foreign market. This tends to favor subsidiaries, which are more capital demanding. Alvarez-Gil et al. (2003) have described the internationalization process of Spanish banks expanding in Latin America. The first step of this pattern consisted of implementing representative offices before the 1990s, then controlling more and more local banks (through partial- then full-share purchases). These observations support the idea that the higher the experience of internationalization, the higher the capital commitment abroad, in order to avoid uncertainty.

H6a. Experience of internationalization facilitates market entry in distant countries.

H6b. Experience of internationalization favors the subsidiary and the branch as entry modes for foreign banks, and has a negative impact on choosing the representative office.

\subsubsection{Distance from the Host Country}

'Geographical distance' is defined as the physical distance between the home country and the host country. The assumption is that the greater the geographical distance, the lower the level of familiarity with the local environment - a factor that is likely to penalize a foreign entrant in favor of local firms in the host country (Hennart, 1982). Distance may have an influence on location choice, since firms tend to favor commercial ventures or operations in a proximate environment. Geographical distance generally increases the costs of information, adaptation and coordination, and so has a negative impact on entry. Examining transition economies, Bevan and Estrin (2004) emphasized the positive impact of the geographical proximity of the home country and host country. Buch (2005) showed that the negative influence of geographical distance had not decreased as a result of technological progress a factor that is assumed to reduce the costs of information processing associated to distance.

Distance can also be measured in cultural or linguistic terms. Customer relationships are a key dimension of banking, and cultural factors are assumed to play an important role. However, Blandón (1998) showed that the influence of cultural distance depends on the type of activity in which banks are involved in foreign markets. Cultural distance is assumed to be a greater barrier to entry for banks targeting the retail banking market in the host country. This can be explained by the high sensitivity of 'local' private customers to the national origin of the company, a factor that automatically penalizes foreign banks. When seeking to internationalize their operations, firms tend to reduce their capital commitment where there is significant cultural distance (Tihanyi et al., 2005). Therefore, it is predicted that banks will opt primarily for representative offices in countries with a different language and culture. Hsieh et al. (2010) show that relatively high cultural distance favors representative office in order to avoid uncertainty. Additionally, Focarelli and Pozzolo $(2005,2008)$ argue that the difference in language between the country of origin and the host country plays negatively on the entry decision - more so for the subsidiary than for the branch.

H7a. In seeking to enter a foreign market, banks target the geographically and culturally closest countries.

H7b. When distance is high, the representative office is preferred to the subsidiary and the branch as the entry mode for foreign banks.

As discussed above, foreign-market entry is a highly complex operation, particularly in the banking sector. In addition to the factors that need to be considered to explain location choice, there is simultaneously the question of entry-mode choice. Table 1 summarizes our hypotheses relating to the impact of each factor on both the likelihood of entry and the choice of organizational form. 
Table 1. Hypotheses

\begin{tabular}{|c|c|c|c|c|c|c|}
\hline & \multirow[b]{2}{*}{ Hypothesis } & \multirow[b]{2}{*}{$\begin{array}{c}\text { Likelihood } \\
\text { of entry }\end{array}$} & \multirow[b]{2}{*}{ Hypothesis } & \multicolumn{3}{|c|}{ Organizational form } \\
\hline & & & & Subsidiary & Branch & $\begin{array}{c}\text { Representative } \\
\text { office }\end{array}$ \\
\hline \multicolumn{7}{|l|}{ Factors related to the host market } \\
\hline Strict regulation & H1a & - & $\mathrm{H} 1 \mathrm{~b}$ & - & + & $?$ \\
\hline High economic development & $\mathrm{H} 2 \mathrm{a}$ & + & $\mathrm{H} 2 \mathrm{~b}$ & + & - & - \\
\hline High taxation rate & $\mathrm{H} 3 \mathrm{a}$ & - & $\mathrm{H} 3 \mathrm{~b}$ & - & + & $?$ \\
\hline High country-risk & $\mathrm{H} 4 \mathrm{a}$ & - & $\mathrm{H} 4 \mathrm{~b}$ & - & + & $?$ \\
\hline \multicolumn{7}{|l|}{ Factors related to the parent bank } \\
\hline Large size & $\mathrm{H} 5 \mathrm{a}$ & + & $\mathrm{H} 5 \mathrm{~b}$ & ++ & - & - \\
\hline Experience of internationalization & H6a & + & $\mathrm{H} 6 \mathrm{~b}$ & ++ & + & - \\
\hline Distance from the host country & $\mathrm{H} 7 \mathrm{a}$ & - & $\mathrm{H} 7 \mathrm{~b}$ & - & - & + \\
\hline
\end{tabular}

\section{RESEARCH METHODOLOGY}

\subsection{Sample and Data Collection}

The banks included in the sample are among the 100 largest banking institutions in the world (based on total assets). Among the 100 banks, the sample included only banks that had entered at least five foreign markets at the time of the study (and for which data were available). The final sample included 63 banks from 18 countries (Table 2). The data are from the Bankscope database (2004). The number of available observations is not sufficient to perform statistical tests for each host country. Although it is not the most appropriate method, given the significant differences in regulatory and institutional frameworks (including between neighboring countries), the analysis of the location choice of foreign banks was conducted based on distinct geographical areas. The economic and regulatory data relate to five different regions: Africa, Latin and Central America, Eastern Europe, Southeast Asia, and the Middle East. These categories are often used by organizations such as the OECD, United Nations Conference on Trade and Development (UNCTAD), World Bank and IMF, and are also sometimes used in academic research. For example, Geringer et al. (1989) used these categories to examine the influence of diversification and internationalization strategies on performance. Similarly, Kwok and Tadesse (2006) adopted a continental approach to characterizing the financial system of 42 countries, arguing that a continental distribution reflects a degree of homogeneity from a cultural point of view, particularly in terms of the aversion to uncertainty. The typologies developed by Hofstede (1980) and Ronen and Shenkar (1985) are more elaborate. In this study, two types of distance - geographical distance and cultural distance (measured by language similarity) - will be used explicitly, through explanatory variables.

Table 2. Distribution of the sample of foreign banks by home country

\begin{tabular}{|c|c|}
\hline Home country & Number \\
\hline Australia & 3 \\
\hline Austria & 1 \\
\hline Belgium & 3 \\
\hline Canada & 5 \\
\hline China & 3 \\
\hline France & 6 \\
\hline Germany & 10 \\
\hline India & 1 \\
\hline Ireland & 1 \\
\hline Italy & 4 \\
\hline Japan & 4 \\
\hline Netherlands & 3 \\
\hline South Korea & 2 \\
\hline Spain & 2 \\
\hline United Kingdom & 4 \\
\hline United States & 7 \\
\hline Sweden & 2 \\
\hline Switzerland & 2 \\
\hline Total & 63 \\
\hline
\end{tabular}


In seeking to enter a foreign market, banks are required not merely to select a particular location but also to select the entry mode best adapted to the specific characteristics of the host country and to their own characteristics. Table 3 provides statistical data relating to the geographical distribution of banks included in the sample for each entry mode. The analysis of location choice indicates a preference for Asian and South American countries over other areas (Middle East, Africa, and Eastern Europe). The table shows that branches represent 307 of the 784 foreign institutions owned by the 63 banks included in the sample, ahead of representative offices (254) and subsidiaries/affiliated banks (223). However, because of the limited number of observations, it is impossible to distinguish between wholly owned subsidiaries, regular subsidiaries controlled by the parent company, and affiliated banks. Finally, Table 3 shows that there was no clear preference of organizational form in Africa. By contrast, in Southeast Asian countries, it was found that foreign banks tend to opt for the branch as the preferred entry mode, while subsidiaries tend to be the most popular organizational form in Eastern Europe.

Table 3. Distribution of organizational forms by region

\begin{tabular}{l|c|c|c|c}
\hline & Branch & Subsidiary/affiliated bank & Representative office & Total \\
\hline Africa & 30 & 35 & 38 & $\mathbf{1 0 3}$ \\
\hline Latin and Central America & 67 & 70 & 90 & $\mathbf{2 2 7}$ \\
\hline Eastern Europe & 24 & 52 & 28 & $\mathbf{1 0 4}$ \\
\hline Middle East & 43 & 8 & 34 & $\mathbf{8 5}$ \\
\hline Southeast Asia & 143 & 58 & 64 & $\mathbf{2 6 5}$ \\
\hline Total & $\mathbf{3 0 7}$ & $\mathbf{2 2 3}$ & $\mathbf{2 5 4}$ & $\mathbf{7 8 4}$ \\
\hline
\end{tabular}

\subsection{Definition of Explanatory Variables}

In the previous section, we identified the factors that explain the likelihood of foreign-market entry, and the choice of entry mode. Those factors are related to both the host country (regulation, level of economic development, tax, and risk) and the parent bank (size, experience of internationalization, and geographical and cultural distance from the host country). The loan-to-deposit ratio (which determines the use of market resources) is used as a control variable.

Regulation (REG): This indicator is based on Barth et al. (2003). The value of the indicator is the sum of the binary values associated with its three components - i.e. 'prohibition to operate under a particular legal form', 'prohibition to engage in a particular type of activity', and 'the requirement to produce written documents and statistical data' in order to foster an accurate disclosure, regardless of the capital regulation. For a given country, each component takes value 1 if it is supported and 0 otherwise. This variable, which quantifies regulatory constraints and interdictions, aims to measure the degree of restriction on banking activity (Birindelli and Del Prete, 2010).

Development (DEVEL): The level of development of the banking sector reflects the growth opportunities in the host country (Focarelli and Pozzolo, 2005), and is usually measured by the rate of penetration of banking services, based on the ratio of bank deposits to GDP. The IMF often uses the deposit-to-GDP ratio to identify the most developed and the weakest banking sectors.

Tax rate on banks in the host country (TAX): In terms of taxation, branches have more advantages compared to subsidiaries, since the former are subject to the tax regime of the home country (Cerutti et al., 2007). Since they have no separate legal status, branches transfer their income to the parent firm; this income is therefore exempt from taxation in the host country.

Country-risk (RISK): Country-risk determines the profit opportunities in the host market (Grosse and Goldberg, 1991; Yamori, 1998; Carstensen and Toubal, 2004). To measure this, we used an OECD indicator that defines country-risk as the probability that a country will service its external debt. The OECD uses seven quantitative criteria - including the financial and economic situation, and the experience of countries in the field of payments but also a range of qualitative criteria, such as the political situation. Countries are rated on a scale of 0 (low risk) to 7 (high risk). For each country, a ratio is calculated by comparing the score obtained and the total number of criteria.

Size of the bank (SIZE): Size refers to the financial and human-resource capacity of the bank. In this study, bank size is measured by the natural logarithm of the total number of staff, following Mutinelli and Piscitello (2001). 
Degree of internationalization of the bank (INTER): Experience of internationalization enables a bank to better understand an often complex and turbulent international environment. Following Ursacki and Vertinsky (1992) and Leung et al. (2008), the degree of internationalization was measured by the number of countries in which the bank operates.

Geographical distance between the home country and the host country (DIST): In line with the literature (Hennart, 1982; Buch, 2005; Focarelli and Pozzolo, 2005), distance is viewed as a barrier to internationalization, and entails significant costs for banks seeking to gain information about foreign-market-entry mode and the most effective organizational form. Geographical distance is measured by the natural logarithm of the distance in kilometers between the capital cities of the home country and host country (Cabo, 1997).

Language (LANG): Non-economic factors, such as a common language or culture, also determine the choice of location (Buch, 2003; Focarelli and Pozzolo, 2005). This variable is binary, taking value 1 if the home and host countries have the same official language and 0 otherwise. Linguistic differences may provide an indication of the degree of cultural distance between the home and host countries.

The loan-to-deposit ratio (LDR): This variable can be used to distinguish between retail banking activities characterized by the predominance of banking intermediation (deposit-taking and credit-granting), and financial and investment banking activities. Following Ursacki and Vertinsky (1992), LDR is measured using the balance sheet of the bank. A value higher than 1 indicates that the bank grants more loans than it receives deposits, hence the need to resort to interbank funds and the financial markets.

\subsection{Model}

To reiterate, the aim of the study is to explain simultaneously the location and entry-mode choices, based on the factors associated with the characteristics of the bank and of the host country. With a framework of simultaneous equations, we take into account the endogenous character of both the market-entry mode and the location choice. Furthermore, even entry mode and location choice are explained by the same independent variables. Incidentally, we use the 'three-stage least squares' (3SLS) method. This method is generally used to account simultaneously for two or several variables based on the same explanatory variables, and is deemed to provide better estimation results than the 'ordinary least squares' (OLS) method. The simultaneous equations may therefore be presented as follows:

$$
\begin{aligned}
& \text { Region }_{\mathbf{i}}=\alpha_{0}+\alpha_{1} \text { OFFICE }+\alpha_{2} \text { SUBSID }+\alpha_{3} \text { BRANCH }+\alpha_{4} \text { REG }+\alpha_{5} \text { DEVEL }+\alpha_{6} \text { TAX }+\alpha_{7} \text { RISK }+\alpha_{8} \text { SIZE }+ \\
& \alpha_{9} \text { INTER }+\alpha_{10} \text { LANG }+\alpha_{11} \text { DIST }+\alpha_{12} \text { LDR }+\varepsilon \\
& \text { OFFICE }=\beta_{0}+\beta_{1} \text { Region }_{\mathbf{i}}+\beta_{2} \text { REG }+\beta_{3} \text { DEVEL }+\beta_{4} \text { TAX }+\beta_{5} \text { RISK }+\beta_{6} \text { SIZE }+\beta_{7} \text { INTER }+\beta_{8} \text { LANG }+\beta_{9} \\
& \text { DIST }+\beta_{10} \text { LDR }+\varepsilon \\
& \text { SUBSID }=\gamma_{0}+\gamma_{1} \text { Region }_{\mathbf{i}}+\gamma_{2} \text { REG }+\gamma_{3} \text { DEVEL }+\gamma_{4} \text { TAX }+\gamma_{5} \text { RISK }+\gamma_{6} \text { SIZE }+\gamma_{7} \text { INTER }+\gamma_{8} \text { LANG }+\gamma_{9} \text { DIST } \\
& +\gamma_{10} \text { LDR }+\varepsilon \\
& \text { BRANCH }=\eta_{0}+\eta_{1} \text { Region }_{\mathbf{i}}+\eta_{2} \text { REG }+\eta_{3} \text { DEVEL }+\eta_{4} \text { TAX }+\eta_{5} \text { RISK }+\eta_{6} \text { SIZE }+\eta_{7} \text { INTER }+\eta_{8} \text { LANG }+\eta_{9} \\
& \text { DIST }+\eta_{10} \text { LDR }+\varepsilon
\end{aligned}
$$

The results will be used to determine simultaneously the location preferences of foreign banks and the entry mode based on (1) the characteristics of the host country, such as regulation, level of development of the banking sector, tax, and risk, and (2) the characteristics of the parent bank, such as its size, experience of internationalization, and geographical and cultural distance from the host country.

\section{RESULTS AND DISCUSSION}

Table 4 presents the means and the interregional differences in terms of the explanatory variables regarding the characteristics of the host country by geographical area. The statistical data relating to the level of development of the banking sector (measured by the rate of penetration of banking services) indicate disparate results. Southeast 
Asia has the highest level of development based on the deposit-to-GDP ratio. Eastern Europe and the Middle East are second and third respectively, while Africa, and Central and Latin America, lag far behind. The table shows that the tax regime (measured by the tax rate on banks) is more favorable to foreign-bank entry in the Middle East and Eastern Europe, followed by Southeast Asia, Central and Latin America, and Africa. In terms of country-risk, the criteria used by the OECD indicate that Central and Latin America is the highest-risk area, followed by Africa, the Middle East, and Eastern Europe, while Southeast Asia is the lowest-risk area.

Table 5 reports the results of our model. While the model considers location and entry mode as simultaneous and interdependent decisions, the results provide some answers and suggest a number of avenues for the impact of entry mode on location choice and vice versa. As a rough guide, our results show that when they decide to establish a branch or a representative office overseas, parent banks are more likely to choose Southeast Asia as a foreign location. All other things being equal, the subsidiary is the most likely mode of entry to Latin America and Eastern Europe. Conversely, when they decide to settle in Latin America or Eastern Europe, parent banks choose the subsidiary as their foreign-market-entry mode. Finally, foreign banks are more likely to set up representative offices in the Middle East, and branches in Southeast Asia.

As far as the host country characteristics are concerned, we find that regulation (REG) increases the likelihood of foreign banks establishing themselves in Africa. Based on the results of this study, and in line with the conclusions reached by Rupprecht (2008), strict banking regulations in the host country are not a major obstacle for foreign banks seeking to enter the market. Strict regulations refer to the quality of the institutions responsible for implementing prudential standards (Claessens and Van Horen, 2008). Foreign banks may see this as a condition for financial stability. More specifically, our results show that higher regulatory restrictions - in terms of scope of activity - act as an incentive for banks to opt for Africa as a location choice. Therefore, a tightening of banking regulatory constraints will be viewed favorably only by banks with the ability to target Africa, given the significant capacity of the region to accommodate a greater number of banking institutions. ${ }^{1}$ This is consistent with the results of a study by Eden and Miller (2004), who found that institutional differences tend to reduce capital commitment. A more restrictive regulatory framework in emerging countries equates indirectly to a reduction in the institutional distance between emerging countries and the more developed home countries of the parent banks. Therefore, H1a is supported.

Regarding the entry mode, we assumed that more constraining regulation makes the subsidiary a more likely entry mode than the branch. Our hypothesis H1b is supported, since regulation has a negative and significant impact on the likelihood of establishing branches rather than subsidiaries overseas (except for in Southeast Asia), and a positive and significant impact on representative office as a foreign-market-entry mode. In most cases, the impact of regulation on the choice of subsidiary is negative while not significant. Moreover, even though it is not explicitly addressed by the empirical studies, the influence of written requirements through the regulation of the host country is expected to favor the branch or the representative office above the subsidiary, associated with greater organizational complexity and capital commitment.

Irrespective of the preferred organizational form, the level of development of the banking sector in the host country (DEVEL) - measured by the rate of penetration of banking services - tends not to favor any of the regions considered in our study. Hypothesis H2a, which predicts that banks choose countries with a significant growth potential (measured by the rate of penetration of banking services, based on the ratio of bank deposits to GDP), is not supported. Regardless of the selected region, when the level of economic development is high, the subsidiary associated with bigger operations - is more likely to be used (than the branch or the representative office) as the entry mode for foreign banks. This result is consistent with the study of Focarelli and Pozzolo (2008), who found a positive association between the country's growth prospects and the setting-up of a subsidiary. H2b is then supported.

1 The economic report on Africa published by UNCTAD (2006) showed that Africa had significant needs in the banking sector. The report emphasizes the ill-adapted regulatory framework, explaining the concentration of the banking sector and the very low rates of financial intermediation. 
Table 4. Difference-of-means test of variables relating to the characteristics of the host country

\begin{tabular}{|c|c|c|c|c|c|c|c|c|c|}
\hline \multirow[b]{3}{*}{$\begin{array}{l}\text { Africa versus } \\
\text { Latin America }\end{array}$} & \multicolumn{3}{|c|}{ DEVEL } & \multicolumn{3}{|c|}{ TAX } & \multicolumn{3}{|c|}{ RISK } \\
\hline & \multicolumn{2}{|c|}{ Mean } & \multirow{2}{*}{\begin{tabular}{|r|} 
t-Student \\
$-3.984^{* * *}$ \\
\end{tabular}} & \multicolumn{2}{|c|}{ Mean } & \multirow{2}{*}{$\begin{array}{r}\text { t-Student } \\
2.941^{* * *}\end{array}$} & \multicolumn{2}{|c|}{ Mean } & \multirow{2}{*}{$\begin{array}{r}\text { t-Student } \\
-1.956^{*}\end{array}$} \\
\hline & $\begin{array}{c}0.0426 \\
(0.0339)\end{array}$ & $\begin{array}{c}0.0650 \\
(0.0321)\end{array}$ & & \begin{tabular}{|c|}
0.3489 \\
$(0.0360)$
\end{tabular} & $\begin{array}{c}0.3168 \\
(0.0701)\end{array}$ & & $\begin{array}{c}0.5970 \\
(0.2383)\end{array}$ & $\begin{array}{c}0.6864 \\
(0.2736)\end{array}$ & \\
\hline $\begin{array}{l}\text { Africa versus } \\
\text { Eastern Europe }\end{array}$ & $\begin{array}{c}0.0426 \\
(0.0339)\end{array}$ & $\begin{array}{c}0.5780 \\
(0.7504)\end{array}$ & $-4.775^{* * *}$ & $\begin{array}{c}0.3489 \\
(0.0360)\end{array}$ & $\begin{array}{c}0.2154 \\
(0.0575)\end{array}$ & $13.933^{* * *}$ & $\begin{array}{c}0.5970 \\
(0.2383)\end{array}$ & $\begin{array}{c}0.4130 \\
(0.2390)\end{array}$ & $4.056^{* * *}$ \\
\hline $\begin{array}{l}\text { Africa versus } \\
\text { Middle East }\end{array}$ & $\begin{array}{c}0.0426 \\
(0.0339)\end{array}$ & $\begin{array}{c}0.3504 \\
(0.8809)\end{array}$ & $-2.339^{* *}$ & $\begin{array}{c}0.3489 \\
(0.0360)\end{array}$ & $\begin{array}{c}0.2160 \\
(0.1554)\end{array}$ & $5.642^{* * *}$ & $\begin{array}{c}0.5970 \\
(0.2383)\end{array}$ & $\begin{array}{c}0.4323 \\
(0.1283)\end{array}$ & $5.030^{* * *}$ \\
\hline $\begin{array}{l}\text { Africa versus } \\
\text { Southeast Asia }\end{array}$ & $\begin{array}{c}0.0426 \\
(0.0339)\end{array}$ & $\begin{array}{c}16.8187 \\
(25.0569)\end{array}$ & $-4.484^{* * *}$ & $\begin{array}{c}0.3489 \\
(0.0360)\end{array}$ & $\begin{array}{c}0.2710 \\
(0.0399)\end{array}$ & $11.891^{* * *}$ & $\begin{array}{c}0.5970 \\
(0.2383)\end{array}$ & $\begin{array}{c}0.3892 \\
(0.3226)\end{array}$ & $4.041^{* * *}$ \\
\hline $\begin{array}{l}\text { Latin America } \\
\text { versus Eastern } \\
\text { Europe }\end{array}$ & $\begin{array}{c}0.0650 \\
(0.0321)\end{array}$ & $\begin{array}{c}0.5780 \\
(0.7504)\end{array}$ & $-7.887^{* * *}$ & $\begin{array}{c}0.3168 \\
(0.0701)\end{array}$ & $\begin{array}{c}0.2154 \\
(0.006)\end{array}$ & $10.492^{* * *}$ & $\begin{array}{c}0.6864 \\
(0.2736)\end{array}$ & $\begin{array}{c}0.4130 \\
(0.2390)\end{array}$ & $7.133^{* * *}$ \\
\hline $\begin{array}{l}\text { Latin America } \\
\text { versus Middle } \\
\text { East }\end{array}$ & $\begin{array}{c}0.0650 \\
(0.0321)\end{array}$ & $\begin{array}{c}0.3504 \\
(0.8809)\end{array}$ & $-3.739^{* * *}$ & $\begin{array}{c}0.3168 \\
(0.0701)\end{array}$ & $\begin{array}{c}0.2160 \\
(0.1554)\end{array}$ & $6.469^{* * *}$ & $\begin{array}{c}0.6864 \\
(0.2736)\end{array}$ & $\begin{array}{c}0.4323 \\
(0.1283)\end{array}$ & $7.803^{* * *}$ \\
\hline $\begin{array}{l}\text { Latin America } \\
\text { versus Southeast } \\
\text { Asia }\end{array}$ & $\begin{array}{c}0.0650 \\
(0.0321)\end{array}$ & $\begin{array}{c}16.8187 \\
(25.0569)\end{array}$ & $-7.708^{* * *}$ & $\begin{array}{c}0.3168 \\
(0.0701)\end{array}$ & $\begin{array}{c}0.2710 \\
(0.0399)\end{array}$ & $7.209^{* * *}$ & $\begin{array}{c}0.6864 \\
(0.2736)\end{array}$ & $\begin{array}{c}0.3892 \\
(0.3226)\end{array}$ & $8.534^{* * *}$ \\
\hline $\begin{array}{l}\text { Eastern Europe } \\
\text { versus Middle } \\
\text { East }\end{array}$ & $\begin{array}{c}0.5780 \\
(0.7504)\end{array}$ & $\begin{array}{c}0.3504 \\
(0.8809)\end{array}$ & 1.704 & $\begin{array}{c}0.2154 \\
(0.0575)\end{array}$ & $\begin{array}{c}0.2160 \\
(0.1554)\end{array}$ & -0.030 & $\begin{array}{c}0.4130 \\
(0.2390)\end{array}$ & $\begin{array}{c}0.4323 \\
(0.1283)\end{array}$ & -0.628 \\
\hline $\begin{array}{l}\text { Eastern Europe } \\
\text { versus Southeast } \\
\text { Asia }\end{array}$ & $\begin{array}{c}0.5780 \\
(0.7504)\end{array}$ & $\begin{array}{c}16.8187 \\
(25.0569)\end{array}$ & $-5.492^{* * *}$ & $\begin{array}{c}0.2154 \\
(0.0575)\end{array}$ & $\begin{array}{c}0.2710 \\
(0.0399)\end{array}$ & $-8.675^{* * *}$ & $\begin{array}{c}0.4130 \\
(0.2390)\end{array}$ & $\begin{array}{c}0.3892 \\
(0.3226)\end{array}$ & 0.564 \\
\hline $\begin{array}{l}\text { Middle East } \\
\text { versus Southeast } \\
\text { Asia }\end{array}$ & $\begin{array}{c}0.3504 \\
(0.8809)\end{array}$ & $\begin{array}{c}16.8187 \\
(25.0569)\end{array}$ & $-5.871^{* * *}$ & $\begin{array}{c}0.2160 \\
(0.1554)\end{array}$ & $\begin{array}{c}0.2710 \\
(0.0399)\end{array}$ & $-4.377^{* * *}$ & $\begin{array}{c}0.4323 \\
(0.1283)\end{array}$ & $\begin{array}{c}0.3892 \\
(0.3226)\end{array}$ & 1.151 \\
\hline
\end{tabular}


Table 5. Results for foreign location and market-entry mode of multinational banks

\begin{tabular}{|c|c|c|c|c|c|c|c|c|}
\hline Variables & Africa & OFFICE & SUBSID & BRANCH & $\begin{array}{c}\text { Latin } \\
\text { America }\end{array}$ & OFFICE & SUBSID & BRANCH \\
\hline OFFICE & $\begin{array}{c}-0.081 * * * \\
(-3.26)\end{array}$ & & & & $\begin{array}{l}-0.080 * * * \\
(-3.59)\end{array}$ & & & \\
\hline SUBSID & $\begin{array}{c}-0.014 \\
(-0.61) \\
\end{array}$ & & & & $\begin{array}{l}0.048^{* *} \\
(2.32)\end{array}$ & & & \\
\hline BRANCH & $\begin{array}{l}-0.056^{* *} \\
(-2.25)\end{array}$ & & & & $\begin{array}{l}-0.073 * * * \\
(-3.24)\end{array}$ & & & \\
\hline Region & & $\begin{array}{c}-0.244 * * * \\
(-2.52)\end{array}$ & $\begin{array}{r}0.061 \\
(0.67) \\
\end{array}$ & $\begin{array}{c}-0.062 \\
(-0.66) \\
\end{array}$ & & $\begin{array}{c}-0.335 * * * \\
(-3.15)\end{array}$ & $\begin{array}{l}0.401 * * * \\
(4.03)\end{array}$ & $\begin{array}{l}-0.202 * * \\
(-1.95)\end{array}$ \\
\hline REG & $\begin{array}{l}0.356^{* * *} \\
(11.94)\end{array}$ & $\begin{array}{c}0.260 * * * \\
(3.58)\end{array}$ & $\begin{array}{c}-0.093 \\
(-1.36) \\
\end{array}$ & $\begin{array}{l}-0.139 * * \\
(-1.97)\end{array}$ & $\begin{array}{c}-0.024 \\
(-0.92) \\
\end{array}$ & $\begin{array}{l}0.164^{* * *} \\
(2.55)\end{array}$ & $\begin{array}{c}-0.059 \\
(-0.99) \\
\end{array}$ & $\begin{array}{c}-0.167 * * * \\
(-2.68)\end{array}$ \\
\hline DEVEL & $\begin{array}{r}0.010 \\
(0.96) \\
\end{array}$ & $\begin{array}{l}-0.042 * \\
(-1.91)\end{array}$ & $\begin{array}{l}0.043^{* *} \\
(2.07)\end{array}$ & $\begin{array}{l}-0.046^{* *} \\
(-2.15)\end{array}$ & $\begin{array}{c}-0.015^{*} \\
(-1.67) \\
\end{array}$ & $\begin{array}{l}-0.048^{* *} \\
(-2.18)\end{array}$ & $\begin{array}{l}0.046^{* *} \\
(2.25) \\
\end{array}$ & $\begin{array}{l}-0.048^{* *} \\
(-2.26)\end{array}$ \\
\hline TAX & $\begin{array}{r}0.139 \\
(1.03)\end{array}$ & $\begin{array}{c}-0.201 \\
(-0.68) \\
\end{array}$ & $\begin{array}{c}0.042 \\
(0.16) \\
\end{array}$ & $\begin{array}{r}0.170 \\
(0.60) \\
\end{array}$ & $\begin{array}{l}-0.331 * * * \\
(-2.73)\end{array}$ & $\begin{array}{c}-0.345 \\
(-1.17) \\
\end{array}$ & $\begin{array}{c}0.180 \\
(0.65) \\
\end{array}$ & $\begin{array}{r}0.097 \\
(0.34) \\
\end{array}$ \\
\hline RISK & $\begin{array}{l}0.147 * * * \\
(3.45)\end{array}$ & $\begin{array}{c}0.351 * * * \\
(3.88)\end{array}$ & $\begin{array}{l}0.195^{* *} \\
(2.30)\end{array}$ & $\begin{array}{c}-0.530 * * * \\
(-6.07) \\
\end{array}$ & $\begin{array}{c}-0.009 \\
(-0.25) \\
\end{array}$ & $\begin{array}{l}0.319^{* * * *} \\
(3.58)\end{array}$ & $\begin{array}{l}0.198^{* * * *} \\
(2.38)\end{array}$ & $\begin{array}{c}-0.537 * * * \\
(-6.22)\end{array}$ \\
\hline SIZE & $\begin{array}{c}-0.009 \\
(-1.06) \\
\end{array}$ & $\begin{array}{c}-0.013 \\
(-0.69) \\
\end{array}$ & $\begin{array}{r}0.013 \\
(0.75) \\
\end{array}$ & $\begin{array}{l}0.032^{*} \\
(1.72) \\
\end{array}$ & $\begin{array}{c}-0.002 \\
(-0.29) \\
\end{array}$ & $\begin{array}{c}-0.011 \\
(-0.61) \\
\end{array}$ & $\begin{array}{r}0.014 \\
(0.79) \\
\end{array}$ & $\begin{array}{c}0.031^{*} \\
(1.73)\end{array}$ \\
\hline INTER & $\begin{array}{r}0.013 \\
(1.00) \\
\end{array}$ & $\begin{array}{l}-0.048^{*} \\
(-1.80)\end{array}$ & $\begin{array}{l}0.062 * * * \\
(2.47)\end{array}$ & $\begin{array}{c}0.082 * * * \\
(3.14)\end{array}$ & $\begin{array}{r}0.004 \\
(0.40) \\
\end{array}$ & $\begin{array}{c}-0.049^{*} \\
(-1.83)\end{array}$ & $\begin{array}{l}0.061^{* * * *} \\
(2.42)\end{array}$ & $\begin{array}{c}0.082 * * * \\
(3.16)\end{array}$ \\
\hline DIST & $\begin{array}{c}-0.008 \\
(-0.70) \\
\end{array}$ & $\begin{array}{r}0.013 \\
(0.56) \\
\end{array}$ & $\begin{array}{l}-0.099 * * * \\
(-4.32)\end{array}$ & $\begin{array}{c}0.089 * * * \\
(3.74)\end{array}$ & $\begin{array}{l}-0.291 * * * \\
(-7.80)\end{array}$ & $\begin{array}{l}-0.085^{* *} \\
(-2.10)\end{array}$ & $\begin{array}{r}0.021 \\
(0.57) \\
\end{array}$ & $\begin{array}{c}0.028 \\
(0.72) \\
\end{array}$ \\
\hline LANG & $\begin{array}{l}0.313^{* * *} * \\
(9.19)\end{array}$ & $\begin{array}{l}-0.162^{* *} \\
(-2.04)\end{array}$ & $\begin{array}{l}0.207^{* * *} \\
(2.77)\end{array}$ & $\begin{array}{r}0.081 \\
(1.05) \\
\end{array}$ & $\begin{array}{l}-0.086^{* * *} \\
(-2.80)\end{array}$ & $\begin{array}{c}-0.263 * * * \\
(-3.57)\end{array}$ & $\begin{array}{l}0.251^{* * * *} \\
(3.66)\end{array}$ & $\begin{array}{c}0.048 \\
(0.69) \\
\end{array}$ \\
\hline LDR & $\begin{array}{r}-0.001 \\
(-1.20) \\
\end{array}$ & $\begin{array}{r}0.000 \\
(0.12)\end{array}$ & $\begin{array}{c}-0.002 \\
(-1.45) \\
\end{array}$ & $\begin{array}{l}0.003 * * \\
(2.05) \\
\end{array}$ & $\begin{array}{c}-0.000 \\
(-0.23) \\
\end{array}$ & $\begin{array}{r}0.000 \\
(0.17) \\
\end{array}$ & $\begin{array}{c}-0.002 \\
(-1.36) \\
\end{array}$ & $\begin{array}{l}0.003 * * \\
(2.03)\end{array}$ \\
\hline Intercept & $\begin{array}{r}0.090 \\
(0.70) \\
\end{array}$ & $\begin{array}{l}0.565^{* *} \\
(2.04) \\
\end{array}$ & $\begin{array}{l}0.715^{* * *} \\
(2.75)\end{array}$ & $\begin{array}{l}-0.619 * * \\
(-2.31)\end{array}$ & $\begin{array}{l}2.863 * * * \\
(4.56)\end{array}$ & $\begin{array}{l}1.521^{* * *} \\
(3.67)\end{array}$ & $\begin{array}{c}-0.443 \\
(-1.14) \\
\end{array}$ & $\begin{array}{c}-0.039 \\
(-0.10) \\
\end{array}$ \\
\hline $\begin{array}{l}\mathrm{R}^{2} \\
\text { Chi2 } \\
\text { Prob }\end{array}$ & $\begin{array}{c}0.4105 \\
363.54 \\
0.0000\end{array}$ & $\begin{array}{c}0.0832 \\
52.13 \\
0.0000\end{array}$ & $\begin{array}{l}0.0957 \\
53.66 \\
0.0000\end{array}$ & $\begin{array}{c}0.1456 \\
86.14 \\
0.0000\end{array}$ & $\begin{array}{c}0.6759 \\
1096.31 \\
0.0000\end{array}$ & $\begin{array}{c}0.0834 \\
55.79 \\
0.0000\end{array}$ & $\begin{array}{c}0.0961 \\
69.89 \\
0.0000\end{array}$ & $\begin{array}{c}0.1457 \\
89.68 \\
0.0000\end{array}$ \\
\hline
\end{tabular}

$*, * *$ and ${ }^{* * *}$ : respective significance thresholds $-10 \%, 5 \%$ and $1 \%$.

\begin{tabular}{|c|c|c|c|c|c|c|c|c|}
\hline Variables & $\begin{array}{l}\text { Eastern } \\
\text { Europe }\end{array}$ & OFFICE & SUBSID & BRANCH & $\begin{array}{l}\text { Middle- } \\
\text { East }\end{array}$ & OFFICE & SUBSID & BRANCH \\
\hline OFFICE & $\begin{array}{c}0.124 * * * \\
(3.23)\end{array}$ & & & & $\begin{array}{r}0.023 \\
(0.60) \\
\end{array}$ & & & \\
\hline SUBSID & $\begin{array}{l}0.127 * * * \\
(3.54)\end{array}$ & & & & $\begin{array}{l}-0.235^{* * *} \\
(-6.59) \\
\end{array}$ & & & \\
\hline BRANCH & $\begin{array}{c}-0.093 * * * \\
(-2.43)\end{array}$ & & & & $\begin{array}{c}-0.026 \\
(-0.70) \\
\end{array}$ & & & \\
\hline Region & & $\begin{array}{l}0.264 * * * \\
(4.30)\end{array}$ & $\begin{array}{l}0.175^{* * *} \\
(3.02)\end{array}$ & $\begin{array}{l}-0.306^{* * *} \\
(-5.16) \\
\end{array}$ & & $\begin{array}{l}0.183^{* * *} \\
(2.95) \\
\end{array}$ & $\begin{array}{l}-0.411 * * * \\
(-7.20) \\
\end{array}$ & $\begin{array}{r}-0.027 \\
(-0.44) \\
\end{array}$ \\
\hline REG & $\begin{array}{r}0.026 \\
(0.57) \\
\end{array}$ & $\begin{array}{l}0.160 * * * \\
(2.49)\end{array}$ & $\begin{array}{l}-0.081 \\
(-1.34) \\
\end{array}$ & $\begin{array}{l}-0.144^{* *} \\
(-2.33) \\
\end{array}$ & $\begin{array}{l}-0.082 * \\
(-1.80)\end{array}$ & $\begin{array}{l}0.185^{* * *} \\
(2.87)\end{array}$ & $\begin{array}{c}-0.095 \\
(-1.60)\end{array}$ & $\begin{array}{l}-0.162 * * * \\
(-2.60)\end{array}$ \\
\hline DEVEL & $\begin{array}{l}-0.012 \\
(-0.74) \\
\end{array}$ & $\begin{array}{l}-0.044^{* *} \\
(-2.00)\end{array}$ & $\begin{array}{l}0.045^{* *} \\
(2.19)\end{array}$ & $\begin{array}{l}-0.049 * * \\
(-2.33)\end{array}$ & $\begin{array}{c}0.009 \\
(0.62) \\
\end{array}$ & $\begin{array}{l}-0.045^{* *} \\
(-2.09)\end{array}$ & $\begin{array}{l}0.043^{* *} \\
(2.14)\end{array}$ & $\begin{array}{l}-0.047 * * \\
(-2.20)\end{array}$ \\
\hline TAX & $\begin{array}{r}0.122 \\
(0.59) \\
\end{array}$ & $\begin{array}{c}-0.259 \\
(-0.89) \\
\end{array}$ & $\begin{array}{r}0.037 \\
(0.14) \\
\end{array}$ & $\begin{array}{r}0.187 \\
(0.66) \\
\end{array}$ & $\begin{array}{l}-1.128 * * * \\
(-5.45)\end{array}$ & $\begin{array}{c}-0.026 \\
(-0.09) \\
\end{array}$ & $\begin{array}{c}-0.421 \\
(-1.50) \\
\end{array}$ & $\begin{array}{r}0.131 \\
(0.45) \\
\end{array}$ \\
\hline RISK & $\begin{array}{c}0.617 * * * \\
(9.34)\end{array}$ & $\begin{array}{c}0.120 \\
(1.21)\end{array}$ & $\begin{array}{c}0.076 \\
(0.82)\end{array}$ & $\begin{array}{l}-0.315^{* * * *} \\
(-3.28)\end{array}$ & $\begin{array}{l}0.127^{* *} \\
(1.93)\end{array}$ & $\begin{array}{l}0.296^{* * * *} \\
(3.31)\end{array}$ & $\begin{array}{l}0.245^{* * * *} \\
(2.97)\end{array}$ & $\begin{array}{l}-0.537 * * * \\
(-6.20)\end{array}$ \\
\hline
\end{tabular}

\footnotetext{
$*, * *$ and ${ }^{* * *}$ : respective significance thresholds $-10 \%, 5 \%$ and $1 \%$.
}

(Panel B continued on next page) 
(Panel B continued)

\begin{tabular}{|c|c|c|c|c|c|c|c|c|}
\hline Variables & $\begin{array}{l}\text { Eastern } \\
\text { Europe }\end{array}$ & OFFICE & SUBSID & BRANCH & $\begin{array}{c}\text { Middle- } \\
\text { East }\end{array}$ & OFFICE & SUBSID & BRANCH \\
\hline SIZE & $\begin{array}{r}0.013 \\
(1.02)\end{array}$ & $\begin{array}{c}-0.013 \\
(-0.71)\end{array}$ & $\begin{array}{c}0.010 \\
(0.61)\end{array}$ & $\begin{array}{l}0.036^{* *} \\
(1.96)\end{array}$ & $\begin{array}{c}0.012 \\
(0.93)\end{array}$ & $\begin{array}{l}-0.012 \\
(-0.64)\end{array}$ & $\begin{array}{c}0.016 \\
(0.93)\end{array}$ & $\begin{array}{l}0.032 * \\
(1.77)\end{array}$ \\
\hline INTER & $\begin{array}{c}-0.013 \\
(-0.71) \\
\end{array}$ & $\begin{array}{c}-0.046^{*} \\
(-1.71)\end{array}$ & $\begin{array}{l}0.067 * * * \\
(2.64)\end{array}$ & $\begin{array}{l}0.075^{* * *} \\
(2.90)\end{array}$ & $\begin{array}{c}0.033^{*} \\
(1.73)\end{array}$ & $\begin{array}{l}-0.054^{* *} \\
(-2.01)\end{array}$ & $\begin{array}{l}0.069^{* * * *} \\
(2.79)\end{array}$ & $\begin{array}{l}0.081 \text { *** } \\
(3.13)\end{array}$ \\
\hline DIST & $\begin{array}{l}0.169^{* * *} \\
(9.41)\end{array}$ & $\begin{array}{c}-0.022 \\
(-0.88) \\
\end{array}$ & $\begin{array}{l}-0.126 * * * \\
(-5.16)\end{array}$ & $\begin{array}{l}0.135^{* * *} \\
(5.38)\end{array}$ & $\begin{array}{c}-0.000 \\
(-0.01)\end{array}$ & $\begin{array}{r}0.012 \\
(0.53) \\
\end{array}$ & $\begin{array}{l}-0.091 * * * \\
(-4.03)\end{array}$ & $\begin{array}{l}0.090^{* * * *} \\
(3.80)\end{array}$ \\
\hline LANG & $\begin{array}{c}-0.171 * * * \\
(-3.23)\end{array}$ & $\begin{array}{l}-0.195 * * * \\
(-2.65)\end{array}$ & $\begin{array}{l}0.258^{* * *} \\
(3.73)\end{array}$ & $\begin{array}{r}0.006 \\
(0.09) \\
\end{array}$ & $\begin{array}{l}-0.109^{* *} \\
(-2.07)\end{array}$ & $\begin{array}{l}-0.211^{* * *} \\
(-2.86)\end{array}$ & $\begin{array}{l}0.158^{* *} \\
(2.30)\end{array}$ & $\begin{array}{c}0.056 \\
(0.79) \\
\end{array}$ \\
\hline LDR & $\begin{array}{l}-0.011 * * * \\
(-11.16)\end{array}$ & $\begin{array}{l}0.003^{* *} \\
(2.22)\end{array}$ & $\begin{array}{c}0.000 \\
(0.05) \\
\end{array}$ & $\begin{array}{c}-0.001 \\
(-0.47) \\
\end{array}$ & $\begin{array}{l}-0.004^{* * *} \\
(-4.52)\end{array}$ & $\begin{array}{r}0.001 \\
(0.81) \\
\end{array}$ & $\begin{array}{l}-0.004 * * * \\
(-2.77)\end{array}$ & $\begin{array}{l}0.003 * * \\
(1.99)\end{array}$ \\
\hline Intercept & $\begin{array}{c}-1.615^{* * *} \\
(-8.08)\end{array}$ & $\begin{array}{l}0.918^{* * *} \\
(3.17)\end{array}$ & $\begin{array}{l}0.964 * * * \\
(3.54)\end{array}$ & $\begin{array}{l}-1.05^{* * *} \\
(-3.77)\end{array}$ & $\begin{array}{c}0.288 \\
(1.45) \\
\end{array}$ & $\begin{array}{l}0.521^{*} \\
(1.88)\end{array}$ & $\begin{array}{l}0.780^{* * * *} \\
(3.04)\end{array}$ & $\begin{array}{l}-0.620 * * \\
(-2.31)\end{array}$ \\
\hline $\begin{array}{l}\mathrm{R}^{2} \\
\text { Chi2 } \\
\text { Prob }\end{array}$ & $\begin{array}{c}0.3955 \\
378.89 \\
0.0000\end{array}$ & $\begin{array}{c}0.0839 \\
64.53 \\
0.0000\end{array}$ & $\begin{array}{l}0.0960 \\
62.56 \\
0.0000\end{array}$ & $\begin{array}{c}0.1465 \\
113.50 \\
0.0000\end{array}$ & $\begin{array}{c}0.1287 \\
128.55 \\
0.0000\end{array}$ & $\begin{array}{c}0.0836 \\
54.51 \\
0.0000\end{array}$ & $\begin{array}{c}0.0980 \\
106.53 \\
0.0000\end{array}$ & $\begin{array}{c}0.1456 \\
85.89 \\
0.0000\end{array}$ \\
\hline
\end{tabular}

$*, * *$ and $* * *$ : respective significance thresholds $-10 \%, 5 \%$ and $1 \%$.

Panel C

\begin{tabular}{|c|c|c|c|c|}
\hline Variables & $\begin{array}{c}\text { Southeast } \\
\text { Asia }\end{array}$ & OFFICE & SUBSID & BRANCH \\
\hline OFFICE & $\begin{array}{r}0.013 \\
(0.39)\end{array}$ & & & \\
\hline SUBSID & $\begin{array}{l}0.073^{* *} \\
(2.31) \\
\end{array}$ & & & \\
\hline BRANCH & $\begin{array}{l}0.245^{* * *} \\
(7.23)\end{array}$ & & & \\
\hline Region & & $\begin{array}{l}-0.293 * * * \\
(-4.24)\end{array}$ & $\begin{array}{r}0.093 \\
(1.43)\end{array}$ & $\begin{array}{l}0.526^{* * *} \\
(8.08)\end{array}$ \\
\hline REG & $\begin{array}{l}-0.275^{* * *} \\
(-6.71)\end{array}$ & $\begin{array}{r}0.082 \\
(1.21)\end{array}$ & $\begin{array}{l}-0.042 \\
(-0.66)\end{array}$ & $\begin{array}{c}0.006 \\
(0.09)\end{array}$ \\
\hline DEVEL & $\begin{array}{r}0.007 \\
(0.52)\end{array}$ & $\begin{array}{l}-0.046^{* *} \\
(-2.11)\end{array}$ & $\begin{array}{l}0.044^{* *} \\
(2.13)\end{array}$ & $\begin{array}{l}-0.046^{* *} \\
(-2.20)\end{array}$ \\
\hline TAX & $\begin{array}{l}1.199^{* * *} \\
(6.48)\end{array}$ & $\begin{array}{c}0.125 \\
(0.41)\end{array}$ & $\begin{array}{l}-0.064 \\
(-0.22)\end{array}$ & $\begin{array}{l}-0.491^{*} \\
(-1.69)\end{array}$ \\
\hline RISK & $\begin{array}{c}-0.883 * * * \\
(-15.08)\end{array}$ & $\begin{array}{r}0.023 \\
(0.21)\end{array}$ & $\begin{array}{l}0.297 * * * \\
(2.81)\end{array}$ & $\begin{array}{l}-0.015 \\
(-0.15)\end{array}$ \\
\hline SIZE & $\begin{array}{l}-0.014 \\
(-1.23) \\
\end{array}$ & $\begin{array}{l}-0.012 \\
(-0.65)\end{array}$ & $\begin{array}{r}0.013 \\
(0.75) \\
\end{array}$ & $\begin{array}{l}0.035^{* *} \\
(1.97) \\
\end{array}$ \\
\hline INTER & $\begin{array}{l}-0.036^{* *} \\
(-2.12)\end{array}$ & $\begin{array}{l}-0.055^{* *} \\
(-2.05)\end{array}$ & $\begin{array}{l}0.064 * * * \\
(2.55)\end{array}$ & $\begin{array}{l}0.088 * * * \\
(3.43)\end{array}$ \\
\hline DIST & $\begin{array}{l}0.131^{* * *} \\
(8.21)\end{array}$ & $\begin{array}{l}0.059 * * \\
(2.25)\end{array}$ & $\begin{array}{l}-0.114 * * * \\
(-4.58)\end{array}$ & $\begin{array}{r}0.013 \\
(0.52)\end{array}$ \\
\hline LANG & $\begin{array}{r}0.053 \\
(1.13)\end{array}$ & $\begin{array}{l}-0.219 * * * \\
(-2.99)\end{array}$ & $\begin{array}{l}0.220^{* * *} \\
(3.19)\end{array}$ & $\begin{array}{c}0.018 \\
(0.26)\end{array}$ \\
\hline LDR & $\begin{array}{l}0.017 * * * \\
(18.69)\end{array}$ & $\begin{array}{l}0.005^{* * *} \\
(2.96)\end{array}$ & $\begin{array}{l}-0.004 * * \\
(-2.07)\end{array}$ & $\begin{array}{l}-0.006 * * * \\
(-3.56)\end{array}$ \\
\hline Intercept & $\begin{array}{l}-0.627 * * * \\
(-3.54)\end{array}$ & $\begin{array}{r}0.337 \\
(1.20)\end{array}$ & $\begin{array}{l}0.786^{* * *} \\
(2.98)\end{array}$ & $\begin{array}{l}-0.244 \\
(-0.91)\end{array}$ \\
\hline $\begin{array}{l}\mathrm{R}^{2} \\
\text { Chi2 } \\
\text { Prob }\end{array}$ & $\begin{array}{c}0.5931 \\
825.29 \\
0.0000\end{array}$ & $\begin{array}{l}0.0843 \\
64.05 \\
0.0000\end{array}$ & $\begin{array}{l}0.0958 \\
55.31 \\
0.0000\end{array}$ & $\begin{array}{c}0.1492 \\
153.89 \\
0.0000\end{array}$ \\
\hline
\end{tabular}

The results in Table 5 show that the tax regime (TAX) favors foreign-market entry in Southeast Asia. The effect of this variable is positive and significant in the case of Southeast Asia, a region that offers more potential for 
development than any of the other areas examined, based on the descriptive statistics. The choice of Southeast Asia was found to be at the expense of the Middle East and Latin America. Compared with other areas, the tax benefits in Southeast Asia are key in the decision of foreign investors. Therefore, it appears that - according to our hypothesis $\mathrm{H} 3 \mathrm{a}$ - an increase in the tax rate is not seen favorably by foreign banks, which may opt to reduce their involvement in a foreign market in favor of another region, particularly Southeast Asia. Inconsistent with our hypothesis H3b, the impact of the tax regime on foreign-market-entry mode is in most cases not significant.

An increasing country-risk reduces the probability of foreign-bank entry in Southeast Asia and enhances their entry likelihood in Africa, Eastern Europe and the Middle East. Hence, our hypothesis H4a seems to be supported only when the macroeconomic risk is initially lower in a given location - which is the case for Southeast Asia, shown in Table 4 to be the lowest-risk area. An increased risk results in a loss of attractiveness. In line with our hypothesis $\mathrm{H} 4 \mathrm{~b}$, when macroeconomic risk is high, branches are less common than subsidiaries in most of the regions considered in our study. As argued by Cerutti et al. (2007), the parent bank has full responsibility for the branch, the preferred organizational form for targeting countries characterized by a low economic risk.

According to Hsieh et al. (2010), there is a positive association between large-scale banking industry and highcontrol foreign-entry modes. Indeed, Table 5 shows that the size of the parent bank determines the choice of the market-entry mode. For any region considered in our study, large banks are more likely to establish themselves overseas through branches. We also show that banks with the greatest experience of internationalization (INTER) tend to enter foreign markets, showing no preference between subsidiaries and branches. The experience of internationalization has a significant and negative impact on the choice of the representative office as a foreignmarket-entry mode. This finding is in line with Blandón (1998), who argues that banks with significant international experience tend to resort to organizational forms that allow a significant level of involvement in the banking industry of the host country. Incidentally, experience of internationalization enables banks to improve their relationships with staff, clients, competitors, and local authorities (Mutinelli and Piscitello, 2001). Hypotheses H5b and $\mathrm{H} 6 \mathrm{~b}$ are hence supported.

Our results regarding the location choice are less conclusive. Bank size is not a significant determinant of location choice. Moreover, our results do not show that foreign banks choose between different geographical areas on the basis of their experience of internationalization. Therefore, hypotheses H5a and H6a are not supported. The geographical distance between the home and host countries tends to favor market entry in both Eastern Europe and Southeast Asia. This result can be explained by the composition of the sample, which included a significant number of European and Asian banks (see Table 2), thus confirming the regional location of multinational firms suggested by Rugman (2005), and Rugman and Verbeke $(2004,2008)$. The results are consistent with the statistical data included in the IMF Global Financial Stability Report (2007), which showed that the majority of FDI by banks entering countries in Central and Eastern Europe originates from neighboring countries within the EU, such as Germany, the Netherlands, and Austria. Rugman (2005) showed that multinationals with a global presence are rare. ${ }^{2}$ Although this finding was established by Flores and Aguilera (2007), the phenomenon of globalization appears to concern only a minority of multinationals. By contrast, a common official language tends to favor foreign-market entry in Africa. This is because many African countries have the same official language and mother tongue as their former colonial powers. Therefore, hypothesis H7a is supported.

Hypothesis $\mathrm{H} 7 \mathrm{~b}$ states that when distance is large, the representative office is preferred to the subsidiary and the branch as an entry mode for foreign banks. Unexpectedly, our results show that an increase in the geographical distance between the foreign bank's home and host countries do not favor the choice of the representative office. However, sharing the same official language seems to favor the subsidiary and to disadvantage the representative office as a foreign-market-entry mode. Hypothesis $\mathrm{H} 7 \mathrm{~b}$ is then rejected.

2 Of the 380 multinationals included in his sample (i.e. drawn from the Fortune 500 companies for which data were available), 320 companies conducted operations on a regional basis. 


\section{CONCLUSION}

The purpose of this study was to explain simultaneously the choice of location and foreign-market-entry mode (branch, subsidiary or representative office), with regard to a set of common factors related to the characteristics of the host country and the parent bank. Based on a sample of 63 banks from 18 countries in 2004, the results highlighted several significant determinants of both foreign-location choice and foreign-market-entry mode. The parent bank's choice of region does not lead to a specific market-entry mode, and vice versa. In addition, the stricter regulatory framework in Africa appears to be a significant factor in attracting foreign banks. Changes in the tax system appear to account for the shift from the Middle East and Latin America to Southeast Asia, while an increased country-risk appears to account for the shift from Southeast Asia to Eastern Europe, the Middle East and Africa. Regarding the characteristics of the parent bank, large banks are more likely to establish themselves overseas through branches while those with the greatest experience of internationalization are more likely to have no preference between subsidiaries and branches. A common official language tends to favor entry in Africa and to favor the subsidiary as the foreign-market-entry mode. Finally, the size of the bank and its experience of internationalization are not significant determinants of location choice.

This study has several limitations. It was based on data relating to 63 banks from 18 countries in 2004, and focused solely on foreign-market entry in emerging or transition countries. In addition to a larger sample, a longer period of analysis would help to highlight possible changes in the behavior of banks (e.g. in crisis periods), and to determine whether individual or temporal differences in the characteristics of banks and home countries better explain foreignlocation choice. It is also important to note that the continental areas used in this study are not designed to reflect any form of cultural, regulatory or institutional homogeneity within each of the studied regions. Data aggregation on a continental basis has the disadvantage of not highlighting national specificities or trends, particularly since there is a considerable degree of economic and regulatory heterogeneity within each continent. This represents a significant limitation.

Another avenue for further research would be to take into account specific characteristics of emerging countries. When the aim is to study foreign-market entry in emerging countries, traditional models based largely on the comparative advantages of firms for studying foreign investments are of limited use (London and Hart, 2004). According to London and Hart, the informal sector plays a significant part in emerging economies, despite not being included in the calculation of either the purchasing power of consumers (which may affect their behavior) or GDP. This point was made in a report published in 2009 by the OECD on the development of financial markets for growth and investment in Africa. The report indicated that "despite the size of the informal economy in most African countries, the formal financial channels typically cover only a portion of the market and do not generally consider the informal sector". Therefore, according to London and Hart (2004), foreign-market entry in emerging countries requires a different strategic approach, which incorporates the formal and informal nature of emerging economies.

\section{AUTHOR BIOGRAPHIES}

Samia Belaounia is a Doctor in management from Dauphine University. She is now an Associate Professor at Neoma Business School. Her Ph.D. dissertation deals with the strategies of the French banking groups. Her main research interests are the internationalization strategies, the determinants of the corporate finance policies and the corporate governance mechanisms, in an international setting. She has published articles in refereed French journals such as Finance Contrôle Stratégie and Revue Française de Gestion. She has reviewed several articles for International Business Review. E mail: samia.belaounia@neoma-bs.fr

Tawhid Chtioui holds a Ph.D. in the University of Paris Dauphine Management Science and Leadership Development Program in Higher Education at the Harvard Graduate School of Education. Author of several scientific articles, he has taught at several schools and universities in France and abroad and has held scientific and management positions in various business schools. He is serial entrepreneur and has held consulting and corporate training activities. Email: tchtioui@groupe-igs.fr

Mehdi Nekhili holds a Ph.D. degree from the University of Burgundy in France. He is now a Professor of Finance at University of Maine (France) and an Affiliated Professor at ICD International Business School (France). His main 
research interests include accounting, auditing, banking and corporate governance. He has published several papers in various refereed journals such as Journal of Business Ethics, Auditing: Journal of Practice and Theory, Journal of Applied Business Research, Managerial Auditing Journal and Review of Accounting and Finance and many chapters in books. He has also edited a book entitled "International Banking Strategies". He has reviewed several articles for Journal of Business Ethics, Journal of Management and Governance, Business Research Quarterly, Journal of Business Research and Asian Business \& Management and many others French reviews. Email: mehdi.nekhili@univ-lemans.fr

\section{REFERENCES}

Alvarez-Gil, M. J., Cardone-Riportella, C. Lado-Couste, N. and Samartin-Saenz, M. (2003). Financial service firms' entry mode choice and cultural diversity: Spanish companies in Latin America. International Journal of Bank Marketing, 21 (3) $109-121$.

Barth, J. R., Caprio, G. Jr., Gand, R. and Levine, R. (2003). Bank supervision and regulation: What works best? Journal of Financial Intermediation, 13 (2) 205-248.

Berger, A., Kashyap, A. K. and Scalise, J. M. (1995). The Transformation of the U.S. Banking Industry: What a long, Strange Trip it's been. Brookings Papers on Economic Activity, 26 55-218.

Bevan, A. A and Estrin, S. (2004). The determinants of foreign direct investment into European transition economies. Journal of Comparative Economics, 32 (4) 775-787.

Birindelli, G. and Del Prete, S. (2010). The internationalization of Italian banks: direction and organizational reshaping. Journal of Money, Investment and Banking, 18 105-127.

Blandón, J. G. (1998). The choice of the form of representation in multinational banking: Evidence from Spain. Economics Working Papers, Department of Economics and Business, Universitat Pompeu Fabra.

Brealey, R. and Kaplanis, E. C. (1996). The determination of foreign banking location. Journal of International Money and Finance, 15 (4) 577-597.

Brewer, P. (2007). Psychic distance and Australian export market selection. Australian Journal of Management, 32 (1) $73-94$.

Buch, C. M. (2000). Why do banks go abroad? Evidence from German data. Journal of Financial Markets, Instruments and Institutions, 9 (1) 33-67.

Buch, C. M. (2003). Information or regulation: what drives the international activities of commercial banks? Journal of Money, Credit and Banking, 35 851-869.

Buch, C. M. (2005). Distance and international banking. Review of International Economics, 13 (4) 787-804.

Cabo, P. G. (1997). The knowledge network. European subsidized research and development cooperation, $\mathrm{PhD}$ thesis, Rijksuniversiteit Gröningen.

Carstensen, K. and Toubal, F. (2004). Foreign direct investment in central and eastern European countries: a dynamic panel analysis. Journal of Comparative Economics, 32 (1) 3-22.

Cerutti, E., Dell'Ariccia, G. and Martínez-Peria, M. S. (2007). How banks go abroad: branches or subsidiaries? Journal of Banking and Finance, 31 (6) 1669-1691.

Claessens, S., Demirgüç-Kunt, A. and Huizinga, H. (2000). The role of foreign banks in domestic banking systems, In S. Claessens and M. Jansen (eds), The internationalization of financial services: Issues and lessons for developing countries, Boston, Kluwer Academic Publishers.

Claessens, S., and Van Horen, N. (2008). Location decisions of foreign banks and institutional competitive advantage. Working paper, University of Amsterdam.

Clarke, G., Cull, R., D'Amato, L. and Molinari, A. (2000). On the kindness of strangers? The impact of foreign bank entry on domestic banks in Argentina, In Claessens S. and M. Jansen (eds.), The Internationalization of Financial Services: Issues and Lessons for Developing Countries, Boston, Mass., Kluwer Academic Press.

Cull, R. and Martinez Peria, M. S. (2007). Foreign bank participation and crises in developing countries. World Bank Policy research, working paper $\mathrm{n}^{\circ} 4128$.

Cull, R. and Martinez Peria, M. S. (2010). Foreign bank participation in developing countries: what do we know about the drivers and consequences of this phenomenon? World Bank Policy research, working paper $n^{\circ} 5398$.

Dell'Ariccia, G. and Marquez, R. (2010). Risk and the corporate structure of banks. Journal of Finance, 65 (3) $1075-1096$.

Douglas, D. and Karunaratna, A. (2006). Developing a multidimensional instrument to measure psychic distance stimuli. Journal of International Business Studies, 37 (5) 578-602.

Dunning, J. H. (2001). Global capitalism at Bay, London and New York, Routledge.

Dunning, J. H. and Lundan, S. M. (2008). Institutions and the OLI paradigm of the multinational enterprise. Asia Pacific Journal of Management, 25 (4) 573-593.

Eden, L. and Miller, S. R. (2004). Distance matters: liability of foreignness, institutional distance and ownership strategy, In Michael A. Hitt; Joseph L.C. Cheng (Eds.), The evolving theory of the multinational firm. Advances in International Management (p. 187-221), Amsterdam: Elsevier.

Fisher, A. and Molyneux, P. (1996). A note on the determinants of foreign bank activity in London between 1980 and 1989. 
Applied Financial Economics, 6 (3) 271-277.

Flores, R. G. and Aguilera, R. V. (2007). Globalization and location choice: an analysis of US multinational firms in 1998 and 2000. Journal of International Business Studies, 38 (7) 1187-1210.

Focarelli, D. and Pozzolo, A. F. (2005). Where do banks expand abroad? An empirical analysis. Journal of Business, 78 (6) 2435-2465.

Focarelli, D. and Pozzolo, A. F. (2008). Cross-border M\&As in the financial sector: is banking different from insurance? Journal of Banking and Finance, 32 (1) 15-29.

Geringer, M. J., Beamish, P. W. and Dacosta, R. C. (1989). Diversification strategy and internationalization: Implications for MNE performance. Strategic Management Journal, 10 (2) 109-119.

Ghemawat, P. (2001). Distance still matters. The hard reality of global expansion. Harvard Business Review, 79 $137-147$.

Goldberg, L. G. and Grosse, R. (1994). Location choice of foreign banks in the United States. Journal of Economics and Business, 46 (5) 367-379.

Goldberg, L. G. and Johnson, D. (1990). The determinants of U.S. banking activity abroad. Journal of International Money and Finance, 9 (2) 123-137.

Goldberg, L. G. and Saunders, A. (1981). The Growth and Organizational Form of Foreign Banks in the U.S. Journal of Money Credit and Banking, 13 365-74.

Grosse, R. and Goldberg, L. G. (1991). Foreign bank activity in the United States: an analysis by country of origin. Journal of Banking and Finance, 15 (6) 1092-1112.

Hennart, J. F. 1982. A theory of multinational enterprise, Ann Arbor: University of Michigan Press.

Hofstede, G. (1980). Culture's consequences: international differences in work-related values, SAGE.

Hryckiewicz, A. and Kowalewski, O. (2010). Economic determinats, financial crisis and entry modes of foreign banks into emerging markets. Emerging Markets Review, 11 (3) 205-228.

Hsieh, M. F., Shen, C. H. and Lee, J. S. (2010). Factors influencing the foreign entry mode of Asian and Latin-American banks. The Service Industries Journal, 30 2351-2365.

International Monetary Fund (2007). Global Financial Stability Report: Markets Developments and Issues, World Economic and Financial Surveys.

Johanson, J. and Vahlne, J. E. (1977). The Internationalization Process of the Firm: A Model of Knowledge Development and Increasing Foreign Market Commitments? Journal of International Business Studies, 8 23-32.

Kwok, C. C. Y. and Tadesse, S. (2006). National culture and financial systems. Journal of International Business Studies, 37 (2) 227-247.

London, T. and Hart, S. L. (2004). Reinventing strategies for emerging markets: beyond the transnational model. Journal of International Business Studies, 35 (5) 1-21.

Leung, M. K., Young, T. and Fung, M. K. (2008). The entry and exit decisions of foreign banks in Hong Kong. Managerial and Decision Economics, 29 (6) 503-512.

Magri, S., Mori, A. and Rossi, P. (2005). The entry and the activity level of foreign banks in Italy: an analysis of the determinants. Journal of Banking \& Finance, 29 (5) 1295-310.

Miller, S. R. and Parkhe, A. (2002). Is there a liability of foreignness in global banking? An empirical test of banks' X-efficiency. Strategic Management Journal, 23 (1) 55-75.

Miller, S. R. and Parkhe, A. (1998). Patterns in the expansion of US banks' foreign operations Journal of International Business Studies, 29 359-390.

Montgomery, H. (2003). The role of foreign banks in Post-crisis Asia: the importance of method of entry. ADB Institute research, Working paper $n^{\circ} 51$.

Moreno, R. and Villar, A. (2005). The increased role of foreign bank entry in emerging markets. Bank of International Settlements, Working paper $\mathrm{n}^{\circ} 23$.

Mutinelli, M. and Piscitello, L. (2001). Foreign direct investment in the banking sector: the case of Italian banks in the 90's. International Business Review, 10 (6) 668-685.

Ronen, S. and Shenkar, O. (1985). Clustering countries on attitudinal dimensions: a review and synthesis. Academy of Management, $10435-454$.

Rugman, A. M. (2005). The regional multinationals, Cambridge, UK, Cambridge University Press.

Rugman, A. M. and Verbeke, A. (2004). A perspective on the regional and global strategies of multinational enterprises. Journal of International Business Studies, 35 (1) 3-18.

Rugman, A. M. and VerbeKe, A. (2008). A regional solution to the strategy and structure of multinationals. European Management Journal, 26 (5) 305-313.

Rupprecht, M., 2008. Bank regulation and the international location choice of banks. Journal of International Business Studies, 8 $176-187$.

Stein, J. (2002). Information production and capital allocation: Decentralized vs. hierarchical firms. Journal of Finance, 57 18911921.

Tihanyi, L., Griffith, D. A. and Russell, C. J. (2005). The effect of cultural distance on entry mode choice, international diversification, and MNE performance: A meta-analysis. Journal of International Business Studies, 36 (3) $270-283$.

Tschoegl, A. E. (1983). Size, growth and transnationality among the World's largest banks. Journal of Business, 56 187-201. 
Tschoegl, A. E. (2004). Who owns the major US subsidiaries of foreign banks? A note. Journal of International Financial Markets. Institutions and Money, 14 (3) 255-266.

UNCTAD. (2010). World Investment Report, United Nations Conference on Trade and Development, New York/Geneva.

UNCTAD (2006). Rapport économique sur l'Afrique, Economic Commission for Africa, Addis Ababa, Ethiopia.

Ursaki, T. and Vertinsky, I. (1992). Choice of entry timing and scale by foreign banks in Japan and Korea. Journal of Banking and Finance, 16 (2) 405-421.

Williamson, O. (1990). The Economic Institutions of Capitalism, second edition, New York, The Free Press.

Yamori, N. (1998). A note on the location choice of multinational banks: the case of Japanese financial institutions. Journal of Banking and Finance, 22 (1) 109-120.

Yeyati, E. L. and Micco, A. (2007). Concentration and foreign penetration in Latin American banking sectors: Impact on competition and risk. Journal of Banking and Finance, 31 (6) 1633-1647. 


\section{NOTES}

